Hydraulic Engineering Repository

Ein Service der Bundesanstalt für Wasserbau

Sinco, Exequiel; Xiao, Ming; Owaidat, Louay M.; Smith, Larry

Slurry Induced Piping Progression of a Sand

Verfügbar unter / Available at:

https://hdl.handle.net/20.500.11970/100309

Vorgeschlagene Zitierweise / Suggested citation:

Sinco, Exequiel; Xiao, Ming; Owaidat, Louay M.; Smith, Larry (2010): Slurry Induced Piping Progression of a Sand. In: Burns, Susan E.; Bhatia, Shobha K.; Avila, Catherine M. C.; Hunt, Beatrice E. (Hg.): Proceedings 5th International Conference on Scour and Erosion (ICSE-5), November 7-10, 2010, San Francisco, USA. Reston, Va.: American Society of Civil Engineers. S. 408-417. 


\title{
Slurry Induced Piping Progression of a Sand
}

\author{
Exequiel Sinco ${ }^{1}$, Ming Xiao ${ }^{2}$, Louay M. Owaidat ${ }^{3}$, and Larry Smith ${ }^{4}$
}

'Graduate Student, Department of Civil and Geomatic Engineering, California State
University, Fresno, CA, USA. Email: esinco@csufresno.edu
${ }^{2}$ Assistant Professor, Department of Civil and Geomatic Engineering, California State
University, Fresno, CA, USA. Email: mxiao@csufresno.edu. Phone: (559) 278-7588.
${ }^{3}$ President, Magnus Pacific Inc., Roseville, CA, USA.
${ }^{4}$ Chief of Construction and Area Engineer, U.S. Army Corps of Engineers, Sacramento, CA,
USA.

\begin{abstract}
The motivation and the first objective of this laboratory experimental research is to study whether bentonite slurry, as a permeating fluid in levees during slurry cutoff wall installation, can induce further piping progression. The second objective of this research is to study the piping progression of a sand under different permeating fluids, which are often observed in the field where seepage carrying fine, suspended particles that are eroded from the upstream soil matrix permeates through a downstream piping channel. A simple constant-head hole-erosion test is used to study the piping progression of the sand subjected to three types of permeating fluids: water, slurry with $6 \%$ bentonite, water mixed with $1 \%$ fines of the same sand that pass the U.S. \#200 sieve. A piping hole is preformed in the sand specimen and a constant hydraulic gradient induces concentrated seepage through the hole. Soil erosion rate and seepage with time and the total soil loss are monitored and measured. The diameters of the piping channels at the end of the tests using the three permeating fluids are quantified and compared. Our experimental results found that higher density of a permeating fluid does not induce more erosion. On the contrary, permeating fluids with fines reduce the eroded soil mass by an average of $90 \%$ and the average piping hole enlargement by $88 \%$, compared with the results using water alone as a permeating fluid. The size distributions of the soils remaining on the inner wall of the piping channels are similar under the three permeating fluids. The agreement of the three particle size distributions suggests that particle deposition on the wall may not occur and is not a mechanism that accounts for the erosion difference.
\end{abstract}

\section{Introduction}

Subsurface erosion in the form of piping has been one of the most prevalent causes of catastrophic failure of levees and earth dams. Such examples include the 1972 failure of the Buffalo Creak dam in West Virginia (Wahler \& Associates, 1973) and the 1990 collapsing of an embankment earth dam in South Carolina (Leonards and Deschamps, 1998). During Hurricane Katrina, three levee breaches were possibly caused by underseepage-induced failure due to piping (Seed et al., 2008a, 2008b). 
Piping is an internal erosion process in which soil particles inside the soil matrix are entrained and washed out of the matrix by concentrated seepage, forming a tubular pipe that progresses from downstream to upstream; the pipe can develop into a large tunnel that may collapse. Erosion tests are used to study the erodibility of soils and to quantify erosion parameters. Common experimental methods for internal erosion include pinhole erosion test (Sherard and Dunnigan, 1989; ASTM, 2006), hole erosion test (Wan and Fell, 2004; Leonards et al., 1991; Reddi et al., 2000; Burns and Ghataora, 2007), and slot erosion test (Sherard et al., 1984; Kohno et al., 1987; Wan and Fell, 2004). In these tests, a hole or a slot is formed in the soil sample housed in a rigid column; the soil is then subjected to a constant hydraulic gradient that induces concentrated seepage through the preformed piping channel.

Dislodging of soil particles is a result of complex hydrodynamic force interactions including electrical forces and stresses between particles, gravity of particles, water pressure around particles and shear stress around particles (Briaud et al., 2008). Kakuturu and Reddi (2006) formulated the hydraulic shear stress $(\tau)$ that exerts on the wall of a piping hole as:

$$
\tau(t)=\frac{4 Q \eta}{\pi \cdot r_{c c}^{3}}
$$

where $Q$ = flow rate, $\eta=$ dynamic viscosity of the permeating fluid, $r_{\mathrm{cc}}=$ radius of the idealized cylindrical core crack. The equation indicates that the physical characteristics of the permeating fluid influence the erosion process. An example is the installation of slurry cutoff walls, which are often used to prevent or remediate internal erosion and reduce seepage in or beneath levees. Slurry, a mixture of water and bentonite, keeps the trench open before the cemented soils are backfilled. When the trench that is filled with slurry intercepts a piping channel, the slurry may displace water and seep through the piping hole. Due to the higher density and viscosity of the slurry than that of water, the slurry may exert higher shear stress and facilitate the internal erosion. Consequently, an enlarged channel is created, causing much higher concentrated seepage. The motivation and the first objective of this research is to study whether bentonite slurry, as a permeating fluid in levees during slurry cutoff wall installation, can induce further piping hole development. The second objective of this research is to study the piping progression of sand under different permeating fluids, which are often observed in the field where seepage carrying fine, suspended particles that are eroded from the upstream soil matrix permeates through a downstream piping channel.

\section{Materials and Methodology}

In the series of experiments, a sandy soil is used. The poorly graded sand has fine content (passing U.S. $\# 200$ sieve) of $17.6 \%$, and $C_{\mathrm{u}}=10, C_{\mathrm{c}}=4$. The sand is reconstituted in a Plexiglas column. The diameter of the specimen is $9.5 \mathrm{~cm}(3.74$ inch) and the length is $30.5 \mathrm{~cm}$ (12 inch). The sand is compacted in 12 uniform layers 
at $95 \%$ of the maximum dry density $\left(\rho_{\mathrm{dmax}}=2.00 \mathrm{~g} / \mathrm{cm}^{3}\right)$ at the optimum water content $\left(w_{\mathrm{opt}}=8.5 \%\right)$ (based on the modified Proctor test). A hole of $0.64 \mathrm{~cm}(1 / 4$ inch) diameter that penetrates the entire specimen is formed during the specimen compaction using a rod of the same diameter. Our preliminary test found that the wall of the pre-made piping hole collapsed during the saturation process when the hole was filled with still water. To study the soil erosion only due to concentrated seepage, $5 \%$ (by mass) kaolinite is mixed with the sand to increase its plasticity. When the sand-clay mixture is compacted at $95 \%$ of the new $\rho_{\text {dmax }}\left(2.10 \mathrm{~g} / \mathrm{cm}^{3}\right)$ at the new $w_{\text {opt }}$ $(8.4 \%)$, the preformed piping hole remained open and the soil particles that detached from the wall of the piping hole during saturation was $1.7 \mathrm{~g}$. The sand-clay mixture is used throughout the experiments.

Table 1. Hole-erosion test program

\begin{tabular}{|c|c|c|}
\hline Permeating fluid & $\begin{array}{l}\text { Measurements in } \\
\text { tests of running time } \\
\quad=10 \mathrm{~min}\end{array}$ & $\begin{array}{l}\text { Measurements in } \\
\text { tests of running time } \\
\quad=40 \mathrm{~min}\end{array}$ \\
\hline De-ionized water & \multirow{3}{*}{$\begin{array}{l}\text { - Erosion rate } \sim \text { time } \\
\text { - Seepage } \sim \text { time } \\
\text { - Particle size } \\
\text { distributions of soils } \\
\text { on the wall of piping } \\
\text { hole }\end{array}$} & \multirow{3}{*}{$\begin{array}{l}\text { - Total dry soil loss } \\
\text { - Piping hole shape } \\
\text { and dimension at the } \\
\text { end of test }\end{array}$} \\
\hline $\begin{array}{l}\text { De-ionized water with } 6.0 \% \\
\text { bentonite (slurry) }\end{array}$ & & \\
\hline $\begin{array}{l}\text { De-ionized water with } 1.0 \% \text { fines } \\
\text { that pass U.S. } \# 200 \text { sieve }\end{array}$ & & \\
\hline
\end{tabular}

A simple constant-head hole-erosion test is used to study the piping progression of the sand subjected to three types of permeating fluids. The test program is summarized in Table $1.6 \%$ of bentonite by mass in slurry is commonly used in slurry walls in the field. The fines in the permeating fluid simulate the suspended particles that are eroded from the upstream section of the same soil. So the fines are obtained by sieving the sand from the same batch that is used to reconstitute the specimens. The fines are mostly silt and non-plastic. The fines concentration in the permeating fluid is $1.0 \%$ by mass. Figure 1 is a photo snapshot of the experimental setup. The water-fines mixture of a specified concentration is prepared in a bucket, in which a submersible pump pumps the mixture into a constant-head reservoir above the specimen. The overflow of the fluid returns back to the bucket. A mechanical stirrer is used to keep the solids (bentonite or fines) in suspension in the bucket and in the upstream reservoir, in an effort to keep the suspended solids concentration as close to the prescribed value as possible. Sufficient amount of permeating fluid is prepared: for the test running time of $40 \mathrm{~min}$, approximately 110 liters of fluid is needed. To prevent the direct impact of the fluid on the inlet of the piping hole, a layer of uniform glass beads is laid on top of the specimen. The outlet of the piping channel opens to the atmosphere. The constant hydraulic gradient is 2.2 . For each permeating fluid, two test periods are used: $10 \mathrm{~min}$ and $40 \mathrm{~min}$. The 10 -min 
period is chosen as a preliminary trial period; then the 40 -min period is chosen because the top portion of the piping channel under de-ionized water enlarged to the perimeter of the mold and the test is stopped at $40 \mathrm{~min}$. In the 10-min tests, the effluent with eroded solids is collected in each 2-min interval. The volume of the effluent is measured and then the effluent is oven-dried to obtain the eroded solid mass. In the 40-min erosion tests, only the dry mass of the eroded solids is obtained by subtracting the dry mass of the specimen after the erosion test from that before the erosion test.

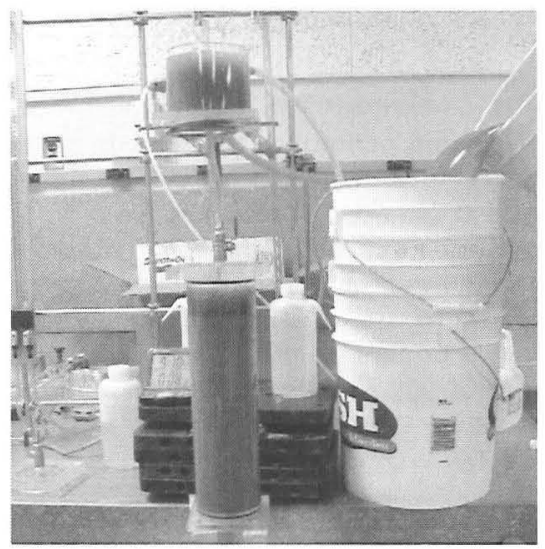

Figure 1. Experimental setup of the hole-erosion tests using different permeating fluids (the fluid shown in the photo contains $1 \%$ fines that pass $\# 200$ sieve)

In the complex interaction of the suspended fines in the permeating fluid and the soil particles on the wall that is exposed to the permeating fluid, the suspended fines may deposit on the wall and consequently protects the piping channel or they may detach the finer solids on the wall (possibly due to the abrasive force) and leave the coarser particles on the wall. To study the effect of different permeating fluids on the fate of the solids on the piping wall and account for the erosion differences under the different permeating fluids, a thin layer (about $2 \mathrm{~mm}$, the accumulative mass is approximately $20 \mathrm{~g}$ ) of the solids is carefully scraped from the wall at the end of each 10 -min erosion test. Then wet sieving and hydrometer tests are conducted on the collected solids from the walls to obtain and compare the particle size distributions of the soil particles left on the walls.

To precisely record the dimension and shape of the piping channel at the end of each test (with the running period of $40 \mathrm{~min}$ ), additional piping tests of the same test condition are performed. At the end of each test, a silicon rubber fluid $\left(\mathrm{OOMOO}^{\mathbb{B}}\right.$ 
25 Silicone Rubber, Smooth-On Inc., Easton, PA) is slowly injected into the piping hole. The fluid occupies the entire voids in the piping channel and solidifies in $75 \mathrm{~min}$ at room temperature. The $\mathrm{OOMOO}^{\circledR} 25$ silicon rubber is used for a variety of artrelated and industrial applications including making molds for sculpture and prototype reproduction. The product has low viscosity $(4250 \mathrm{cps})$ for easy mixing and pouring, and vacuum de-aeration is usually not necessary. It has negligible shrinkage and good tear strength. The solidified silicon rubber can be easily detached from the soil and it accurately represents the shape of the piping hole under different permeating fluids.

\section{Results and Discussion}

In the series of erosion experiments with running time of $40 \mathrm{~min}$, significant erosion is observed when the permeating fluid is de-ionized water - the hole progresses to the perimeter of the mold at $40 \mathrm{~min}$ at the top portion of the specimen and the test is terminated at that time. When using the other fluids with bentonite or non-plastic fines, no noticeable piping progression is observed. The dry soil masses eroded are listed in Table 2. Contrary to our initial hypothesis, fluids with non-plastic fines result in much less soil erosion, even less than that from the bentonite slurry. The permeating fluids with bentonite or fines passing \#200 sieve reduce the eroded soil mass by an average of $90 \%$, compared with the erosion tests using water as permeating fluid.

Table 2. Piping erosion results (40-min erosion period)

\begin{tabular}{l|c}
\hline Permeating fluids & $\begin{array}{c}\text { Dry soil mass } \\
\text { eroded (g) }\end{array}$ \\
\hline De-ionized water & 447.9 \\
\hline De-ionized water with $6.0 \%$ bentonite (slurry) & 51.2 \\
\hline De-ionized water with $1.0 \%$ fines that pass U.S. \#200 sieve & 38.1 \\
\hline
\end{tabular}

In the series of erosion tests with 10 -min running time, similar piping progression and erosion trend are observed as in the tests of 40 -min running time. The seepage variations with time through the specimens under the three permeating fluids are presented in Figure 2. The permeating fluids with bentonite or fines have similar seepage quantity. The progressively increased seepage of water with time is obviously due to the enlarged piping hole as a result of increased erosion. 


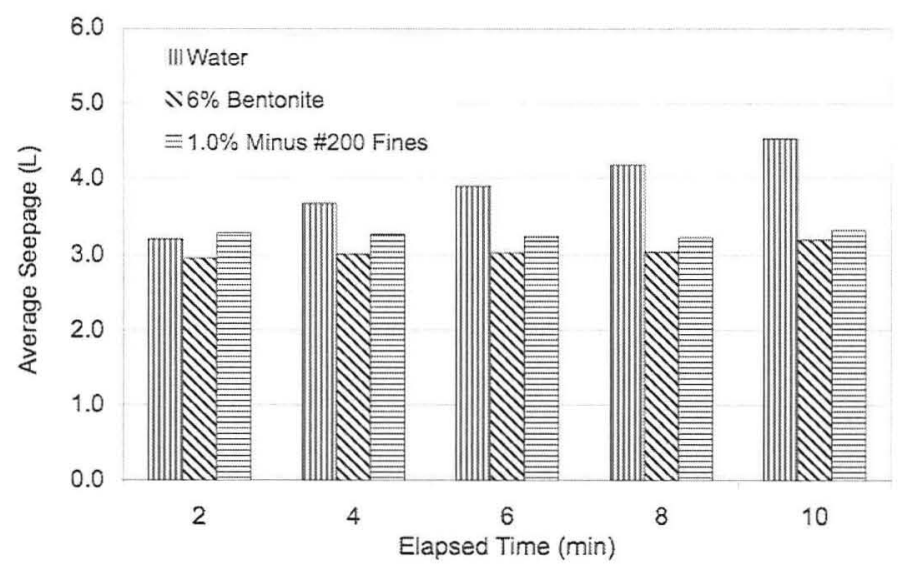

Figure 2. Seepage variations with time in erosion tests of 10-min running time

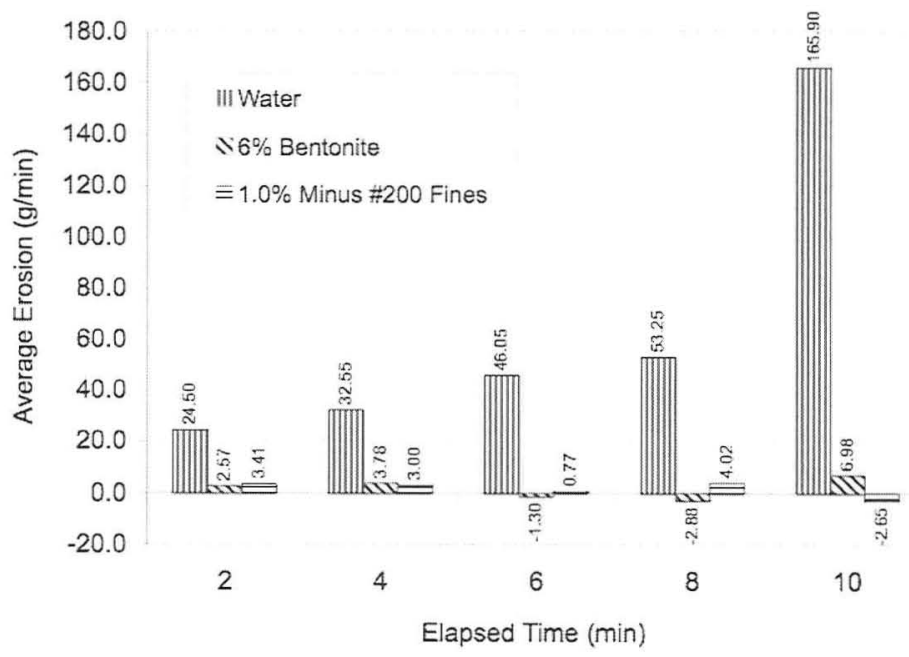

Figure 3. Variations of erosion rate with time in erosion tests of 10 -min running time 
We also attempted to measure the variation of erosion rate (dry eroded soil mass per minute) with time in the three tests of running time of 10 minutes. The results are shown in Figure 3. The effluent with eroded soils and the fines (or bentonite) that are initially in the fluid is collected in every two minutes and ovendried. The dry eroded soil mass is calculated by subtracting the mass of bentonite or fines from the total dry mass collected. An assumption is made in calculating the mass of bentonite or fines in the effluent, i.e., the concentration of the bentonite or fines is constant in the permeating fluid throughout the test. The concentration of the bentonite or fines in the permeating fluid is found by (1) subtracting the total dry mass of the bentonite or fines (including that left in the unused fluid, left in the upstream reservoir, and accumulated in the glass beads and on top of the specimen) from the total dry mass of bentontie or fines used in the permeating fluid preparation, and (2) measuring the total volume of the effluent. The results indicate that the concentrations for bentonite and $1.0 \%$ fines passing \#200 sieve are slightly different from the prescribed values and consequently cause negative erosion values as shown in Figure 3. The seepage of water is much higher than the other permeating fluids, due to increased piping hole. The increase of the seepage of water indicates a progressively increased piping toward failure.

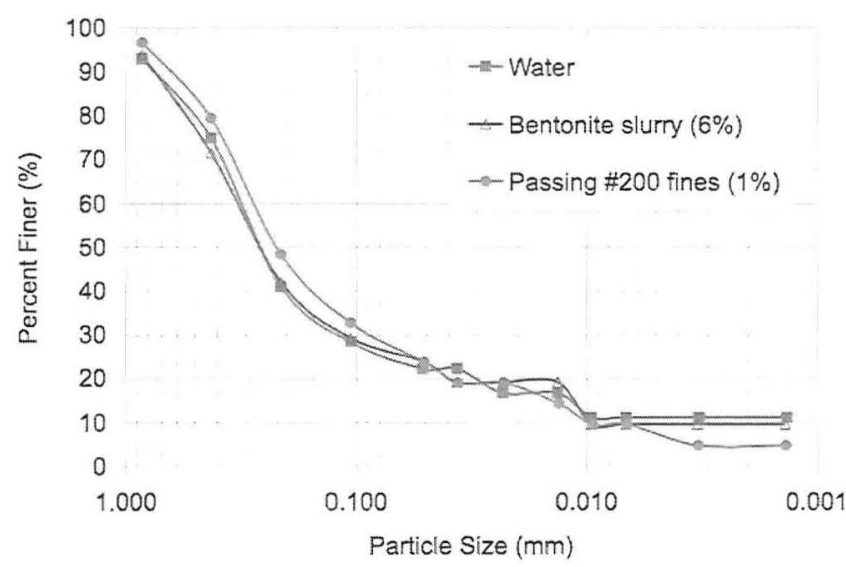

Figure 4. Particle size distributions of soils on the wall of piping hole (10-min running time)

In order to examine whether the slurry or fines deposit on the wall of the piping channel during the erosion test and consequently protect the wall from further erosion, the size distributions of the grains left on the wall at the end of each 10-min erosion test are obtained and shown in Figure 4. The particle size distributions (PSDs) 
from the tests using water, bentonite slurry, or fluids containing fines show no noticeable difference, indicating bentonite or fine particles in the permeating fluid did not deposit on the walls. Agreement of the three PSDs in Figure 4 suggests that particle deposition on the wall may not occur and is not a mechanism that accounts for the erosion difference.

To further investigate the effect of different permeating fluids on the piping progression of the sand, the shapes of the inner piping holes that are molded by the silicon rubber at the end of the 40-min erosion tests are shown Figure 5. We observed that the final shapes of the piping holes in the tests using bentonite and fines have no measurable difference. Therefore, only the silicon rubber from the bentonite slurry erosion test is compared with that from the water erosion test. The bumps on the rubber indicate the non-uniform erosion due to the non-uniform density caused by the specimen compaction in 12 layers. The measurements of the diameters of the piping holes are listed in Table 3. The data show that permeating fluids with fines reduce the average piping hole enlargement by $88 \%$, compared with the results using water as permeating fluid.

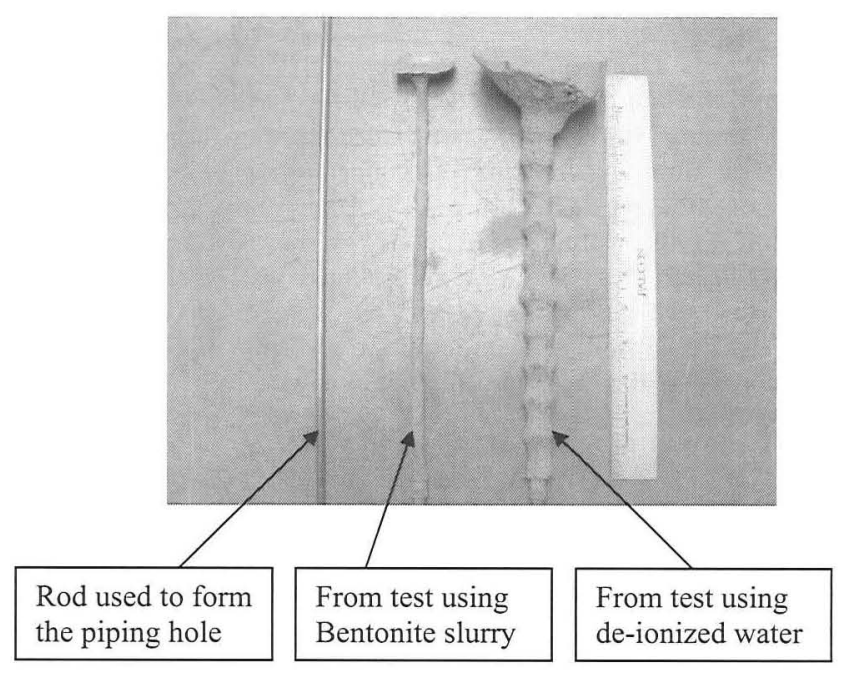

Figure 5. Shapes of piping holes represented by silicon rubber 
Table 3. Final diameters of the piping holes in tests with 40 -min erosion period

\begin{tabular}{c|c|c|c}
\hline Permeating fluids & $\begin{array}{c}\text { Initial hole } \\
\text { diameter } \\
(\mathrm{mm})\end{array}$ & $\begin{array}{c}\text { Average hole } \\
\text { diameter after } \\
\text { test (mm) }\end{array}$ & $\begin{array}{c}\text { Hole diameter } \\
\text { enlargement } \\
(\mathrm{mm})\end{array}$ \\
\hline De-ionized water & 6.4 & 20.5 & 14.1 \\
\hline Bentonite slurry & 6.4 & 8.1 & 1.7 \\
\hline
\end{tabular}

Using the same methodology, we are carrying out a comprehensive experimental program to reveal and quantify the effects of the characteristics of different permeating liquids (in terms of particle sizes, concentrations, and plasticity of fines) on the piping channel progression. Then we will move on to explore the fundamental mechanisms that account for the different piping progression under different permeating fluids.

\section{Conclusions}

This paper reports a laboratory investigation of the piping progression of a sandy soil under three types of permeating fluids. Our experimental results found that higher density of a permeating fluid does not induce more erosion. On the contrary, permeating fluids with slurry or fines of $1 \%$ concentration reduce the eroded soil mass by an average of $90 \%$ and reduce the average piping hole enlargement by $88 \%$, compared with the results using water alone as permeating fluid. The size distributions of the soil particles remaining on the inner wall of the piping channels are similar for the different permeating fluids. The agreement of the particle size distributions suggests that particle deposition on the wall may not occur and is not a mechanism that accounts for the erosion difference.

\section{Acknowledgements}

This research is supported by Magnus Pacific, Inc (Roseville, CA) and the NSF Louis Stokes Alliance for Minority Participation (NSF-LSAMP) Program (grant number: HRD0802628-515291) at California State University.

\section{References}

American Society for Testing and Materials (ASTM) (2006). Standard test method for identification and classification of dispersive clay soils by the pinhole test. 2006 Annual Book of ASTM Standards, Soil and Rock (I), Section 4, Volume 04.08. Designation: D 4647-93. ASTM International. 
Briaud, J.-L., Chen, H.-C., Govindasamy, A.V., Storesund, R. (2008). Levee erosion by overtopping in New Orleans during the Katrina Hurrican. Journal of Geotechnical and Geoenvironmental Engineering, 134(5):618-632. 2008.

Burns, B., and Ghataora, G.S. (2007). Internal Erosion of Kaolin. GSP 162, Problematic Soils and Rocks and In Situ Characterization. GeoDenvor, 2007.

Kakuturu, S., and Reddi, L.N. (2006). Mechanistic model for self-healing of core cracks in earth dams. Journal of Geotechnical and Geoenvironmental Engineering, 132(7):890-901.

Kohno, I, Nishigaki, M, and Takeshita, Y. (1987). Levee failure caused by seepage and preventive measures. Natural Disaster Science, 9(2):55-76.

Leonards, G.A., and Deschamps, R.J. (1998). Failure of Cyanide overflow pond dam. $J$. of Performance of Constructed Facilities, 12(1):3-11.

Leonards, G.A., Huang, A.B., and Ramos, J. (1991). Piping and erosion tests at Conner Run Dam. J. of Geotechnical Engineering, 117(1):108-117.

Reddi, L.N., Lee, I-M., and Bonala, M.V.S. (2000) Comparison of internal and surface erosion using flow pump tests on a sand-kaolinite mixture. Geotechnical Testing Journal, 23(1):116-122.

Seed, R. B., Bea, R.G., Abdelmalak, R. I., Athanasopoulos-Zekkos, A., Boutwell, G.P., Bray, J.D., Cheung, C., Cobos-Roa D., Ehrensing, L., Harder Jr., L.F., Pestana, J.M., Riemer, M.F., Rogers, J.D., Storesund, R., Vera-Grunauer, X, ; and Wartman, J. (2008a). New Orleans and Hurricane Katrina. II: the central region and the lower Ninth Ward. ASCE J. of Geotechnical and Geoenvironmental Engineering, 134(5): 718-739.

Seed, R. B., Bea, R.G., Abdelmalak, R. I., Athanasopoulos-Zekkos, A., Boutwell, G.P., Bray, J.D., Cheung, C., Cobos-Roa D., Cohen-Waeber, J., Collins, B.D., Harder Jr., L.F, Kayen, R.E., Pestana, J.M., Riemer, M.F., Rogers, J.D., Storesund, R., Vera-Grunauer, X, ; and Wartman, J. (2008b). New Orleans and Hurricane Katrina. IV: Orleans East Bank (Metro) Protected Basin. ASCE J. of Geotechnical and Geoenvironmental Engineering, 134(5): 762-779.

Sherard, J.L., Dunnigan, L.P. (1989). Critical filters for impervious soils. ASCE J. of Geotechnical Engineering, 115(7):927-947.

Sherard, J.L., Dunnigan, L.P., Talbot, J.R. (1984). Basic properties of sand and gravel filters. ASCE J. of Geotechnical Engineering, 110(6):684-700.

Wahler, W.A. and Associates. (1973). Analysis of coal refuse dam failure, Middle Fork Buffalo Creek, Saunders West Virginia. National Technical Service Rep. PB-215, Washington, D.C., 142-143.

Wan, C.F., and Fell, R. (2004). Laboratory tests on the rate of piping erosion of soils in embankment dams. ASTM Geotechnical Testing Journal, 27(3):295-303. 